\title{
Induction of thymocyte apoptosis in mice by Yersinia enterocolitica products
}

\author{
Y.-S. LIN, K.-H. CHEN, C.-F. KUO, K.-J. HUANG and J.-J. WU* \\ Department of Microbiology and Immunology and * Department of Medical Technology, National Cheng Kung \\ University Medical College, Tainan, Taiwan, Republic of China
}

\begin{abstract}
In-vivo administration of the culture supernates from Yersinia enterocolitica resulted in thymus atrophy in $\mathrm{C} 3 \mathrm{H} / \mathrm{HeJ}$ mice, known to be lipopolysaccharide (LPS)-nonresponders. The thymocytes underwent apoptosis as characterised by fragmented DNA ladders on agarose gel electrophoresis, a cell death detection ELISA and a morphological study by the TUNEL reaction. As a control, LPS treatment did not induce thymocyte apoptosis in $\mathrm{C} 3 \mathrm{H} / \mathrm{HeJ}$ mice. Flow cytometric analysis indicated that thymus atrophy was due predominantly to the deletion of $\mathrm{CD4}^{+} \mathrm{CD8}^{+} \mathrm{T}$ cells. When cells were undergoing apoptosis, an elevation in the percentage of T-cell receptor (TCR)$\alpha \beta^{\text {high }}$ cells was observed at $24 \mathrm{~h}$, which was correlated with the increase in the percentages of cells expressing high levels of the VB6 and VB8 TCR. Gel electrophoretic analysis demonstrated the presence of protein bands with mol.wts ranging from 17 to $65 \mathrm{kDa}$ in $Y$. enterocolitica culture supernates.
\end{abstract}

\section{Introduction}

Yersinia enterocolitica, a gram-negative coccobacillus belonging to the Enterobacteriaceae, has been associated with human and animal diseases $[1,2]$. These pathogens cause gastro-enteritis; one complication of infection with $Y$. enterocolitica in man has been the subsequent development of autoimmune disease [3-5]. Reactive arthritis stimulated by $Y$. enterocolitica provides an excellent model for the study of pathogenesis of inflammatory arthritis. Recent studies showed that this pathogen activated a Th1-like T-cell subset in patients with Yersinia-triggered reactive arthritis [6-8]. A $19-\mathrm{kDa}$ antigen, which was identical to the urease $\beta$ subunit $[9,10]$, has been shown to act as a target for human synovial $\mathrm{T}$ lymphocytes in reactive arthritis [10]. Nevertheless, the role that bacterial superantigens may play in the development of autoimmune diseases should also be taken into consideration. A number of bacterial T-cell superantigens have been identified, including staphylococcal enterotoxins, streptococcal pyrogenic exotoxins and Mycoplasma arthritidis mitogen [11-13]. Furthermore, Y. pseudotuberculosisderived superantigen has been identified and cloned [14-16]. Y. enterocolitica was reported to produce antigenic material that had properties consistent with those of T-cell superantigens $[17,18]$; however, the

Received 11 April 1997; revised version accepted 10 Sept. 1997.

Corresponding author: Dr Y-S. Lin. superantigen produced by $Y$. enterocolitica has not been characterised.

Induction of apoptosis by bacteria and bacterial products has been reported in macrophages and neutrophils [19-23]. Bacterial superantigen-induced apoptosis in lymphocytes and thymocytes has also been described $[24,25]$. In this study, the effect of $Y$. enterocolitica products on mouse thymus was examined in vivo. The effects of $Y$. enterocolitica products on various thymocyte subpopulations with respect to $\mathrm{CD} 4 / \mathrm{CD} 8$ and specific $\mathrm{T}$-cell receptor (TCR) $\mathrm{V} \beta$-bearing cells were investigated.

\section{Materials and methods}

Mice

Breeding stock of $\mathrm{C} 3 \mathrm{H} / \mathrm{HeJ}$ mice were purchased from the Jackson Laboratory (Bar Harbor, ME, USA) and maintained on standard laboratory chow and water ad libitum in our animal centre. Their progeny, aged 4-6 weeks, were used for the experiments.

\section{Bacterial culture supernate}

The antigen preparation method was modified from the procedure described by Abe et al. [14]. Y. enterocolitica serotype O8 (ATCC 23715) was grown in $2 \mathrm{~L}$ of CYG medium (casamino acid and yeast extract broth supplemented with glucose, $\mathrm{pH} 8.5$ ) at $25^{\circ} \mathrm{C}$ for 5 days 
with vigorous shaking. The culture supernate (SN) was collected by centrifugation at $7000 \mathrm{~g}$ for $30 \mathrm{~min}$, filtered through a $0.22-\mu \mathrm{m}$ filter to remove the residual bacteria, then lyophilised and resuspended in $200 \mathrm{ml}$ of phosphate-buffered saline (PBS). The concentrated SN was precipitated by gradual addition of ammonium sulphate up to $80 \%$, and centrifuged at $10000 \mathrm{~g}$ for $30 \mathrm{~min}$. The precipitates were resuspended in $5 \mathrm{ml}$ of PBS and dialysed against PBS with a 6000-8000mol.wt membrane, then concentrated with a Negative Pressure Micro Protein Dialysis Concentrator (Spectrum Medical Industries, Los Angeles, CA, USA) to 3$5 \mathrm{ml}$. After filtration, the protein concentration was determined by BioRad protein assay (BioRad, Hercules, CA, USA). The CYG medium control was also prepared by the procedure described above but without any bacterial inoculum. The components present in the SN were analysed by SDS-PAGE with a $12.5 \%$ gel, which was loaded with $40 \mu \mathrm{g}$ of proteins (in $20 \mu \mathrm{l}$ ) followed by Coomassie Blue staining.

\section{Measurement of thymus weights and thymocyte numbers}

Mice were inoculated with $Y$. enterocolitica SN preparation or LPS from Escherichia coli serotype O55:B5 (Sigma). Control groups recieved an equivalent volume of PBS or CYG medium alone. After $24 \mathrm{~h}$, mice were killed and the thymus was removed and weighed accurately. Single cell suspensions were then prepared and the cell number was determined with a haemocytometer.

\section{DNA extraction and agarose gel electrophoresis}

Single cell suspensions prepared from thymus glands $\left(1 \times 10^{8}\right.$ in a $1.5-\mathrm{ml}$ microcentrifuge tube $)$ were pelleted and resuspended in cold lysis buffer $(500 \mu \mathrm{l})$ containing $20 \mathrm{mM}$ Tris- $\mathrm{HCl}(\mathrm{pH} 7.4), 10 \mathrm{mM}$ EDTA and Triton $\mathrm{X}-1000.2 \%$ for $10 \mathrm{~min}$, and the lysate was centrifuged for $10 \mathrm{~min}$ at $10000 \mathrm{rpm}$. Then, proteinase $\mathrm{K} 100 \mu \mathrm{g} / \mathrm{ml}$ was added and incubated at $50^{\circ} \mathrm{C}$ for $6 \mathrm{~h}$ and the extract was digested with RNAase at $50 \mu \mathrm{g} / \mathrm{ml}$ for a further $2 \mathrm{~h}$ at $37^{\circ} \mathrm{C}$. The DNA in the viscous solution was extracted twice with phenol and once with chloroform:isoamyl alcohol $(24: 1)$ and then precipitated with 2-propanol $50 \%$ and $1 \mu \mathrm{l}$ of glycogen for $3 \mathrm{~h}$ at $-20^{\circ} \mathrm{C}$. Electrophoresis was performed on agarose $1 \%$ gel in $90 \mathrm{mM}$ Tris-borate buffer ( $\mathrm{pH} \mathrm{8.0)}$ containing $2 \mathrm{mM}$ EDTA. The gel was stained with ethidium bromide $1 \mu \mathrm{g} / \mathrm{ml}$ and visualised with UV light.

\section{Cell death detection ELISA}

Isolated single cell suspensions from thymus were prepared and the fragmented DNA was determined quantitatively with the cell death detection ELISA kit (Boehringer Mannheim GmbH, Mannheim, Germany). The procedure used followed the manufacturer's instructions.

\section{TUNEL reaction}

Mice were treated with $Y$. enterocolitica $\mathrm{SN}$ or CYG medium alone for $24 \mathrm{~h}$, and the presence of apoptotic cells in the thymus was analysed by the terminal deoxytransferase-mediated dUTP nick end-labelling (TUNEL reaction). The ApopTag In Situ Apoptosis Detection Kit for Peroxidase (Oncor, Gaithersburg, MD, USA) was used; tissue fixation and staining procedures used followed the manufacturer's instructions.

\section{Immunofluorescence analysis}

Mouse thymocytes $(50 \mu \mathrm{l})$ at concentration of $2 \times 10^{7} / \mathrm{ml}$ were suspended in Minimum Essential Medium (Life Technologies, Inc., Grand Island, NY, USA) containing sodium azide $0.1 \%$ and fetal calf serum (HyClone) 2\%. Cells were then incubated with various fluorescent-labelled monoclonal antibodies (MAbs) for flow cytometry. The antibodies used included PE-conjugated anti-CD4 (PharMingen, San Diego, CA, USA) and FITC-conjugated anti-CD8 MAb (Boehringer Mannheim GmbH), FITC-conjugated antiTCR- $\alpha \beta$ and FITC-conjugated anti-TCR V $\beta 3,5,6,7$, $8.1,8.2,9,11$ or $13 \mathrm{MAb}$ (PharMingen). After incubation for $30-45 \mathrm{~min}$ on ice, the mixture was washed twice with ice-cold medium and the cells were resuspended in cold medium to approximately $1 \times 10^{6}$ cells $/ \mathrm{ml}$. The stained cells were analysed by flow cytometry (FACScan, Becton Dickinson, Mountain View, CA, USA) with excitation set at $488 \mathrm{~nm}$.

\section{Statistical analysis}

Comparison of TCR $\mathrm{V} \beta$ subpopulations among the three groups was done by analysis of variance (ANOVA) followed by the Duncan multiple range test. Differences were considered significant at $\mathrm{p}<0.05$

\section{Results}

\section{Induction of thymocyte apoptosis by $Y$.} enterocolitica SN preparation

Intraperitoneal administration of $Y$. enterocolitica $\mathrm{SN}$ for $24 \mathrm{~h}$ caused a reduction in thymus weight (Fig. 1a) and thymocyte number (Fig. 1b) as compared to the PBS and CYG medium controls. A similar effect was observed with intravenous injection of the SN (data not shown). The reduction in thymus size and cell number was sustained at $48 \mathrm{~h}$ (data not shown). Furthermore, administration of LPS did not cause thymus atrophy in $\mathrm{C} 3 \mathrm{H} / \mathrm{HeJ}$ mice (Fig. 1). DNA from mouse thymocytes was extracted and analysed by agarose gel electrophoresis. The appearance of fragmented bands of DNA was detected following $Y$. enterocolitica $\mathrm{SN}$ treatment (Fig. 2, lane 3), but not in PBS- (lane 2) and LPStreated (lane 4) groups. The fragmented DNA was further quantified by the cell death detection ELISA. As thymocytes would undergo apoptosis spontaneously, there was a basal level of DNA fragmentation in both 
a

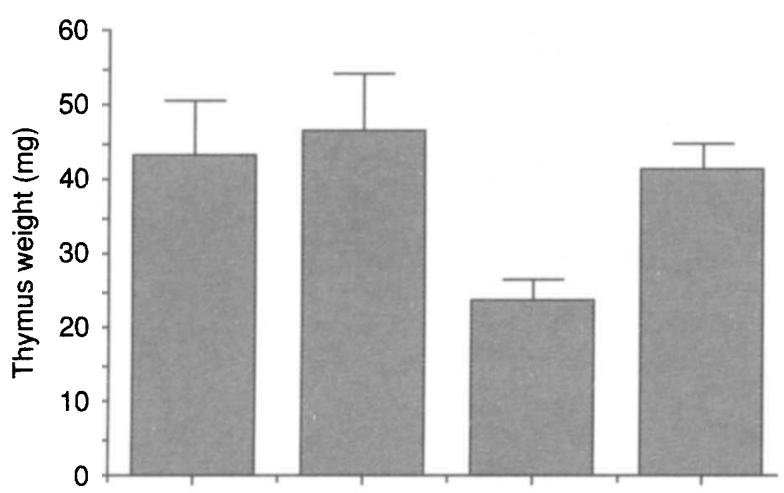

b

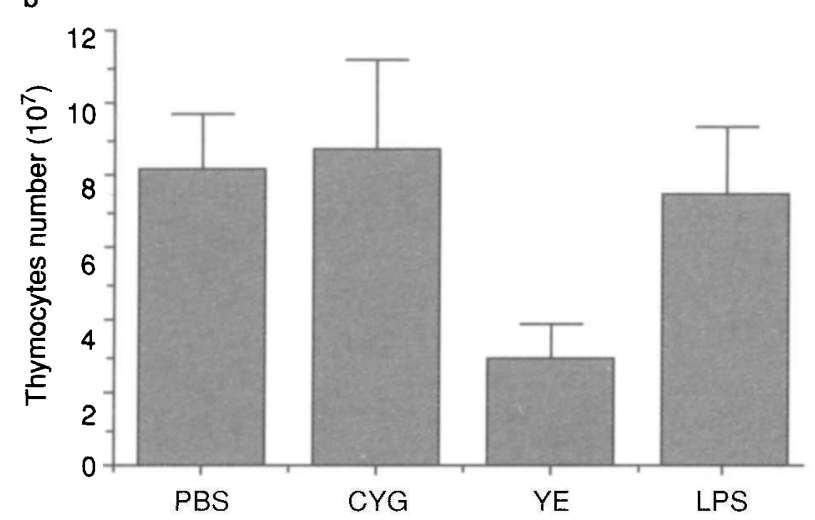

Fig. 1. Effect of $Y$. enterocolitica $\mathrm{SN}$ on mouse thymus. $\mathrm{C} 3 \mathrm{H} / \mathrm{HeJ}$ mice were inoculated with $Y$. enterocolitica concentrated SN (YE, $80 \mu \mathrm{g} ; \mathrm{n}=8)$, LPS $(100 \mu \mathrm{g} ; \mathrm{n}=8)$ or an equivalent volume of PBS $(n=5)$ or CYG medium $(\mathrm{n}=5)$. The thymus weight (a) and cell number $(\mathbf{b})$ were determined after $24 \mathrm{~h}$. Bar indicates the SD.

PBS- and CYG medium-treated controls. Treatment with $Y$. enterocolitica $\mathrm{SN}$ caused an enhancement of DNA fragmentation (Fig. 3). Morphological studies by the TUNEL reaction revealed a higher degree of thymocyte apoptosis in $Y$. enterocolitica $\mathrm{SN}$-treated group than in those mice given control medium (Fig. 4).

The changes in thymocyte subpopulations were examined by flow cytometry. Results indicated a predominant loss of $\mathrm{CD}^{+}{ }^{+} \mathrm{CD}^{+}$cells in the thymus of $Y$. enterocolitica $\mathrm{SN}$-treated mice. Both the percentage (Fig. 5) and yield (Table 1) of $\mathrm{CD}^{+} \mathrm{CD}^{+}$ cells were reduced after treatment. However, LPStreated mice showed a pattern similar to that of the PBS-treated group (Fig. 5, Table 1).

\section{Effects of $Y$. enterocolitica $S N$ on TCR- $\alpha \beta$ and various subsets of $V \beta$-bearing cells}

In addition to the $\mathrm{CD} 4 / \mathrm{CD} 8$ subpopulations, changes in other surface phenotypes during apoptosis were examined. There was an increase in the percentage of TCR- $\alpha \beta^{\text {high }}$ cells (Fig. 6, centre panel) as compared with the PBS-treated control (Fig. 6, upper panel). The changes in thymocytes bearing specific $\mathrm{V} \beta$ elements
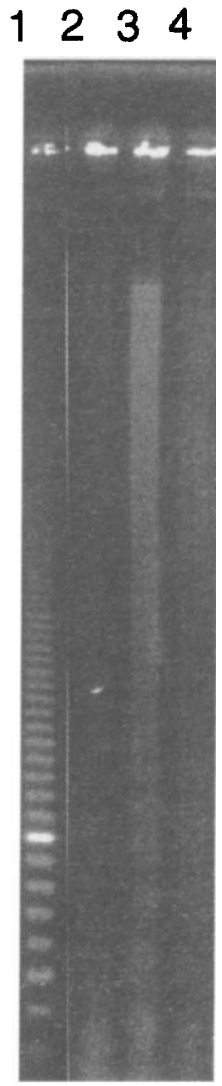

Fig. 2. DNA fragmentation in thymocytes after $Y$. enterocolitica SN administration to mice. DNA was extracted from thymocytes of $\mathrm{C} 3 \mathrm{H} / \mathrm{HeJ}$ mice which were treated with: lane 2, PBS; 3, YE $(80 \mu \mathrm{g})$; or 4 , LPS $(100 \mu \mathrm{g})$ for $12 \mathrm{~h}$. Lane 1, molecular size standards (100 bp DNA ladder marker).

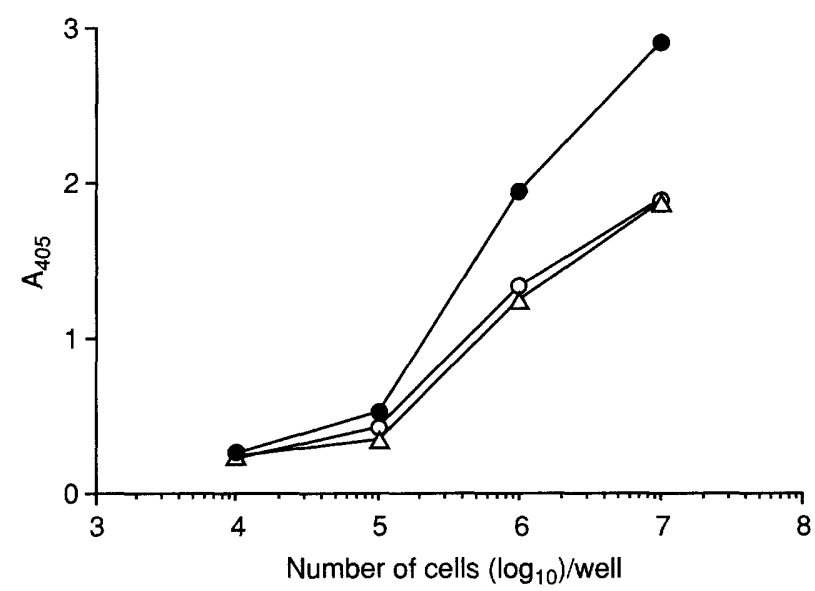

Fig. 3. Quantification of DNA fragmentation levels in mouse thymocytes. DNA was extracted from thymocytes of $\mathrm{C} 3 \mathrm{H} / \mathrm{HeJ}$ mice which were treated with PBS, CYG medium or YE $(400 \mu \mathrm{g})$ for $24 \mathrm{~h}$. The levels of DNA fragmentation were determined by cell death detection ELISA.

were investigated further. Fig. 7a shows the increase in the percentages of $\mathrm{V} \beta 6-$ and $\mathrm{V} \beta 8$-bearing cells $24 \mathrm{~h}$ after administration of $Y$. enterocolitica SN. Data obtained from averages of three experiments are shown 

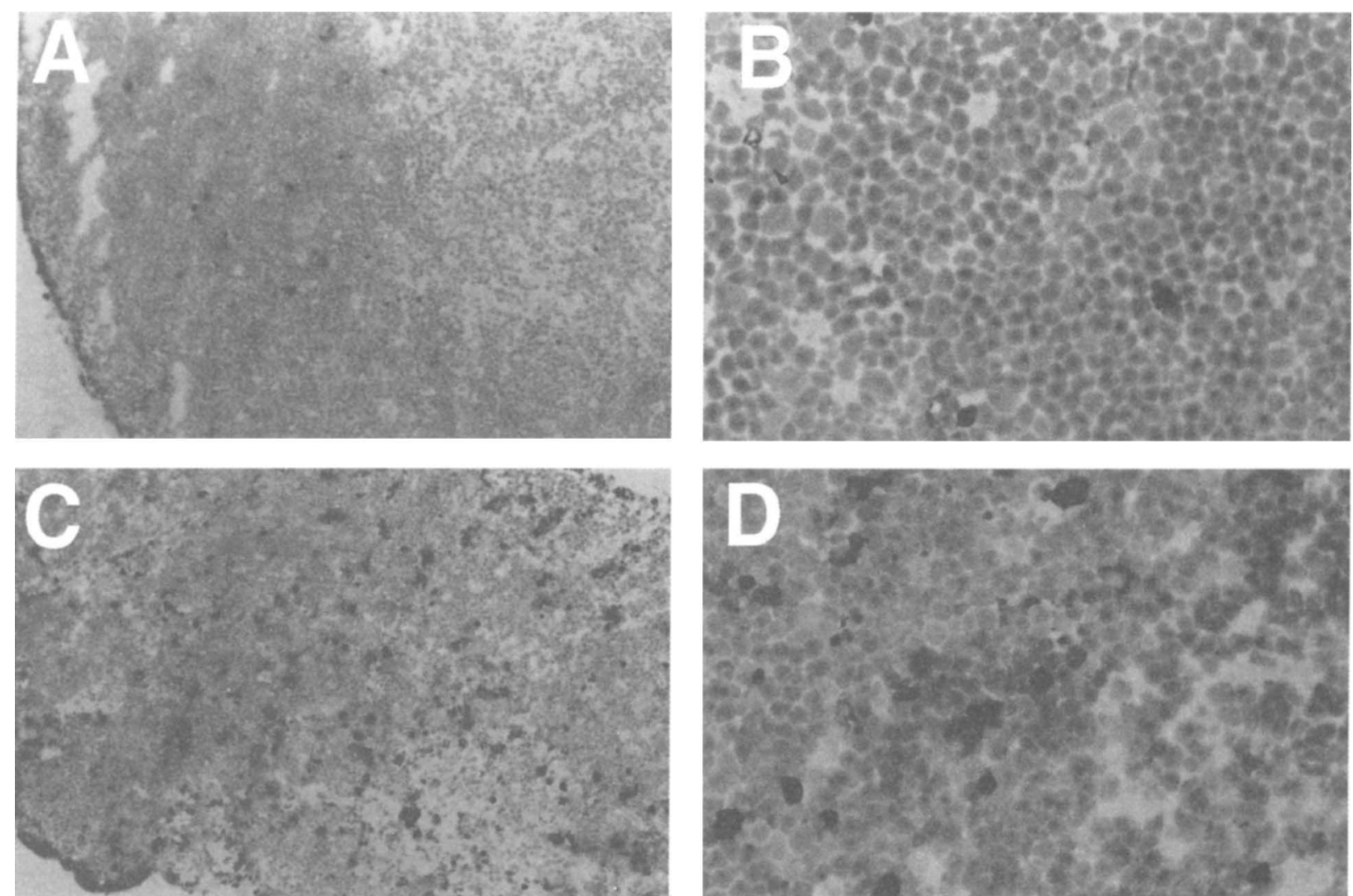

Fig. 4. Morphological study of $Y$. enterocolitica $\mathrm{SN}$-induced thymocyte apoptosis. Mice were treated with CYG medium $($ A, B) or YE $(400 \mu \mathrm{g})(\mathbf{C}, \mathbf{D})$ for $24 \mathrm{~h}$, and the apoptotic cells were analysed by the TUNEL reaction. Magnification, $\times 50(\mathbf{A}, \mathbf{C}) ; \times 190(\mathbf{B}, \mathbf{D})$.

in Fig. 7b. The cells bearing $\mathrm{V} \beta 3,5,7,9,11$ and 13 remained unchanged relative to the PBS-treated control.

As shown in Fig. 6 (lower panel), $\mathrm{C} 3 \mathrm{H} / \mathrm{HeJ}$ mice inoculated with LPS showed a similar percentage of TCR- $\alpha \beta^{\text {high }}$ thymocytes to that of the PBS control. Analysis of the percentages of cells bearing other $\mathrm{V} \beta$ markers also showed levels similar to those of the PBS-treated control (Fig. 7).

\section{Protein patterns in Y. enterocolitica SN}

The protein compositions in $Y$. enterocolitica SN and in the CYG medium were analysed by SDS-PAGE and Coomassie Blue staining. Results showed the presence of protein bands corresponding to mol.wts of 65,52 , $48,45,40,30,27,26,23$ and $17 \mathrm{kDa}$ in $Y$. enterocolitica $\mathrm{SN}$, but not in the medium control (Fig. 8).

\section{Discussion}

The present study demonstrated that $Y$. enterocolitica produced factor(s) that caused depletion of thymocytes. During the process of apoptosis, there was an increase in the percentage of $\operatorname{TCR} \alpha \beta^{\text {high }}$ cells, which was correlated with an increase in the percentages of $\mathrm{V} \beta 6$ and $\mathrm{V} \beta 8$-bearing cells. $\mathrm{A}$ recent report showed upregulation of $\mathrm{TCR} \alpha \beta / \mathrm{CD} 3, \mathrm{CD} 69$ and $\mathrm{CD} 25 \mathrm{ex}-$ pression on dying thymocytes, which led to the suggestion that apoptosis caused a radical alteration in the expression of cell surface molecules [26]. An increase in the expression of $\mathrm{TCR} \alpha \beta / \mathrm{CD} 3$ surface markers on thymocytes during apoptosis induced by staphylococcal enterotoxin B, a bacterial superantigen, has also been found (unpublished data). In this study, the increase in the percentages of TCR $\alpha \beta^{\text {high }}$ cells, especially in $\mathrm{V} \beta 6^{\text {high }}$ and $\mathrm{V} \beta 8^{\text {high }}$ cells, after $Y$. enterocolitica $\mathrm{SN}$ administration was consistent with those previous findings showing upregulation of the expression of cell surface markers.

$Y$. enterocolitica-derived antigens might possess superantigenic activity [17]. The stimulatory activity was found in culture supernates, as well as in membrane and cytoplasmic fractions. With $Y$. enterocolitica cytoplasmic fractions, it was demonstrated that $Y$. enterocolitica stimulated murine $\mathrm{T}$ cells bearing $\mathrm{V} \beta 3$, 6 and 11 and possibly 7 and 9, as well as T-cell hybridomas bearing $\mathrm{V} \beta 3,7,8.1,9$ and 11 , but not 2 , $8.2,8.3$ and 13. As a result of the broad $\mathrm{V} \beta$ repertoire stimulated by $Y$. enterocolitica antigens, it was suggested that this micro-organism might possess multiple superantigens, each of which interacts with 

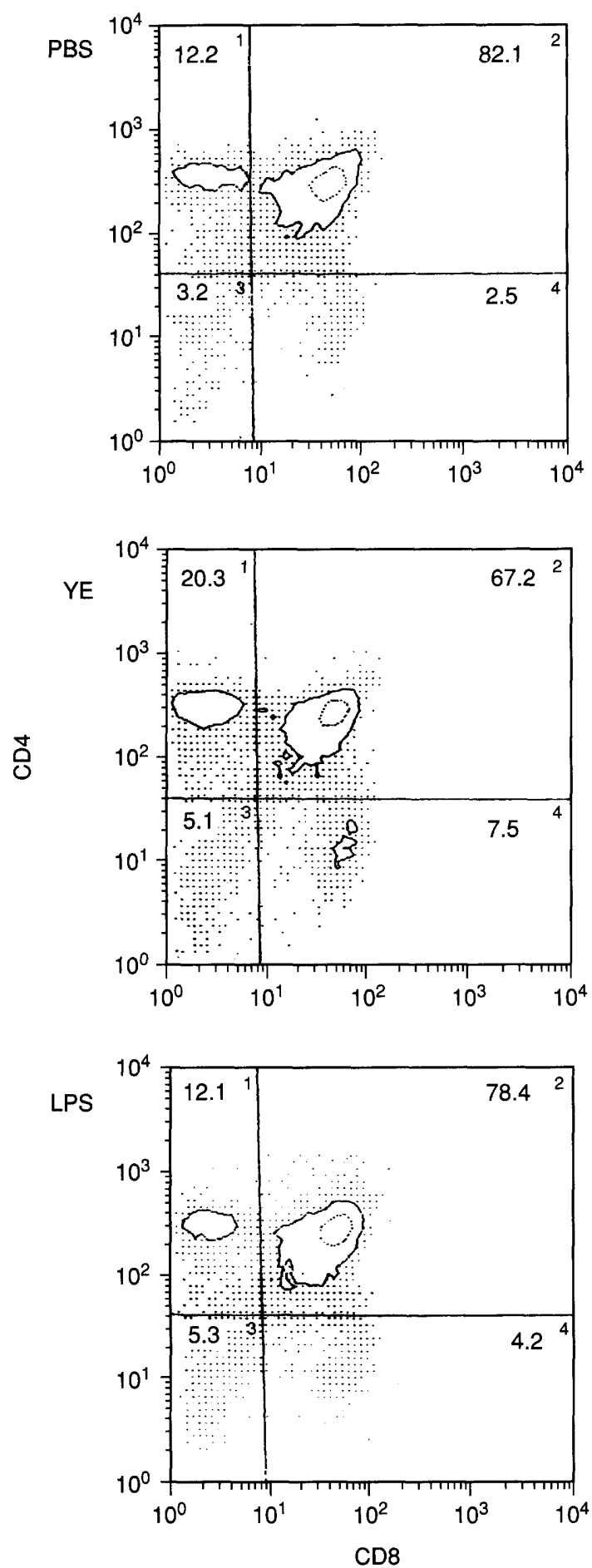

Fig. 5. Changes in CD4/CD8 thymocyte subpopulations after $Y$. enterocolitica $\mathrm{SN}$ administration to mice. Groups of three or four $\mathrm{C} 3 \mathrm{H} / \mathrm{HeJ}$ mice were inoculated with PBS, YE $(80 \mu \mathrm{g})$ or LPS $(100 \mu \mathrm{g})$. After $24 \mathrm{~h}$, the thymocytes were stained with PE-conjugated anti-CD4 and FITC-conjugated anti-CD8 MAb, and analysed by FACScan.

a distinct spectrum of $\mathrm{V} \beta$-bearing $\mathrm{T}$ cells, or alternatively, might have varying binding affinities for different $\mathrm{V} \beta$ [17]. In this study, only $\mathrm{V} \beta 6$ - and $\mathrm{V} \beta 8$-bearing thymocytes appeared to be affected by $Y$. enterocolitica SN preparation. A positive correlation between the presence of $Y$. enterocolitica superantigen
Table 1. Changes in numbers of CD4/CD8 thymocyte subpopulations after $Y$. enterocolitica $\mathrm{SN}$ administration to $\mathrm{C} 3 \mathrm{H} / \mathrm{HeJ}$ mice*

\begin{tabular}{llrrr}
\hline & \multicolumn{4}{c}{ Numbers $\left(\times 10^{6} /\right.$ thymus) (SD) of thymocyte } \\
subpopulations
\end{tabular}

PBS

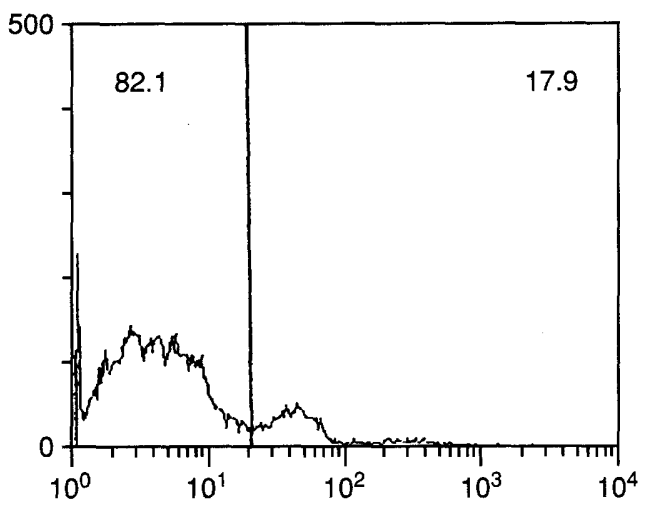

YE

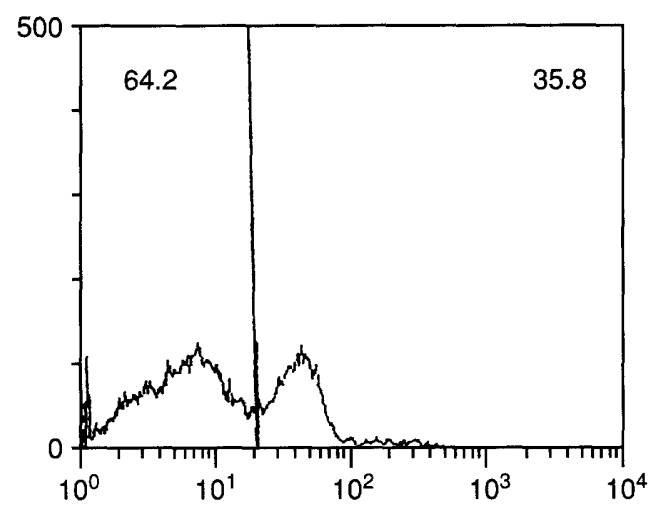

LPS

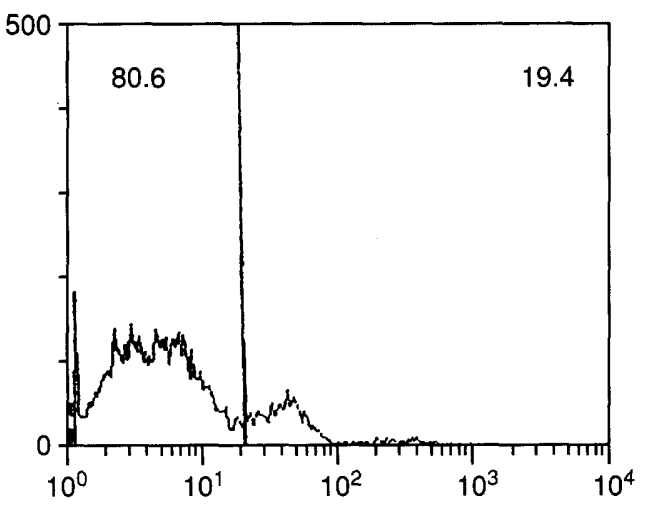

Fig. 6. Increase in TCR- $\alpha \beta^{\text {high }}$ thymocytes after $Y$. enterocolitica SN administration to mice. Groups of three or four $\mathrm{C} 3 \mathrm{H} / \mathrm{HeJ}$ mice were inoculated with $\mathrm{PBS}$, YE $(80 \mu \mathrm{g})$ or LPS $(100 \mu \mathrm{g})$. The thymocytes were stained with FITC-conjugated anti-TCR- $\alpha \beta$ MAb and analysed by FACScan. The percentages of TCR- $\alpha \beta^{\text {high }}$ and TCR- $\alpha \beta^{-/ \text {low }}$ cells are indicated. 

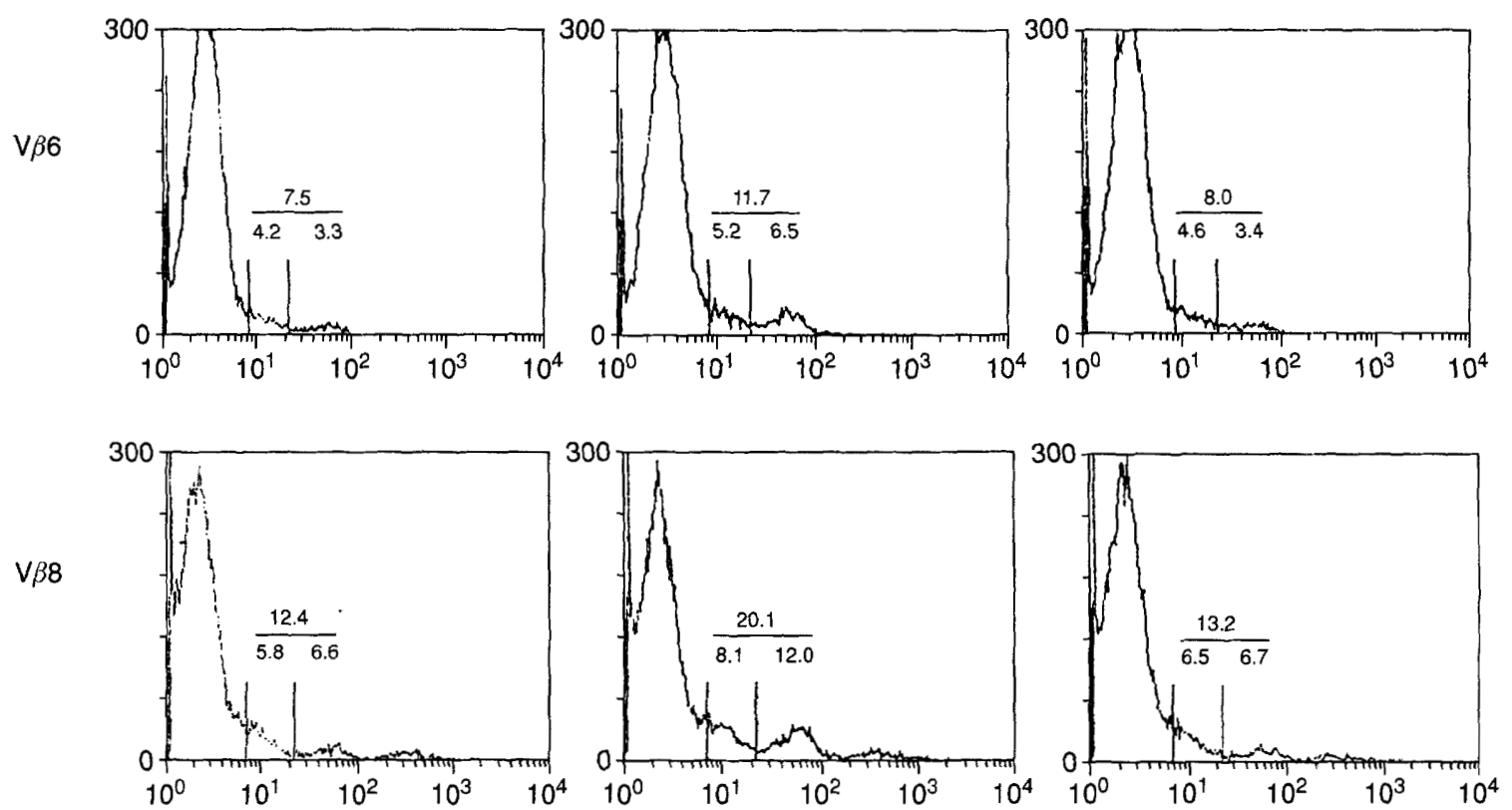

b

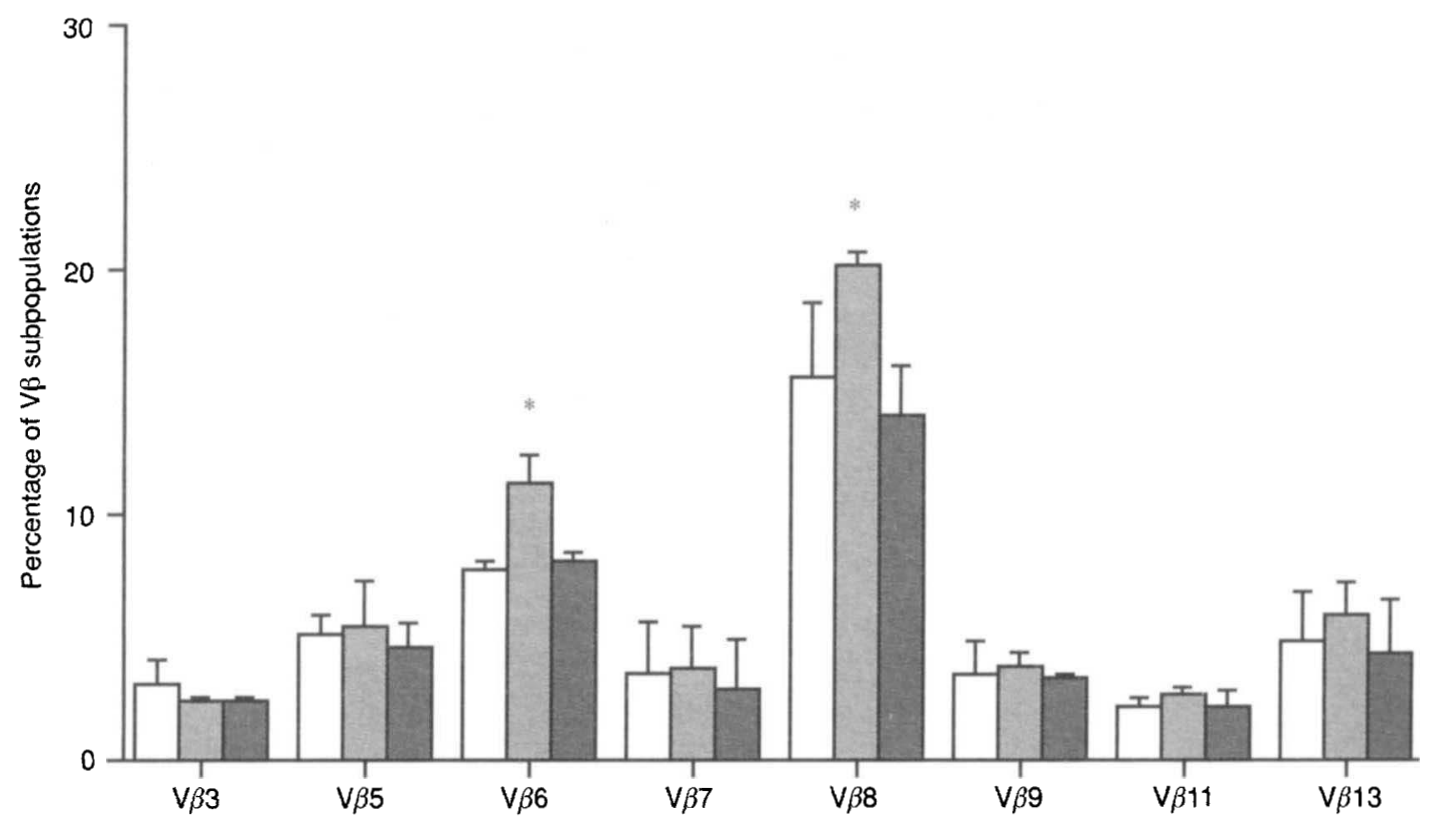

Fig. 7. Effect of $Y$. enterocolitica $\mathrm{SN}$ on thymocytes bearing various $\mathrm{V} \beta$ segments. $\mathrm{C} 3 \mathrm{H} / \mathrm{HeJ}$ mice were inoculated with PBS, YE $(80 \mu \mathrm{g})$ or LPS $(100 \mu \mathrm{g})$. After $24 \mathrm{~h}$, the thymocytes were stained with FITC-conjugated anti-V $\beta 3,5,6,7,8.1$, $8.2,9,11$ or $13 \mathrm{MAb}$, and analysed by FACScan. a, Cells expressing V $\beta 6$ or V $\beta 8.1,8.2 ; \mathbf{b}$, the percentages of various $\mathrm{V} \beta$-bearing cells derived from averages of three experiments. Bar indicates the $\mathrm{SD} ;{ }^{*} \mathrm{p}<0.05$.

in the $\mathrm{SN}$ and the upregulation of these specific $\mathrm{V} \beta$ bearing cells during apoptosis remains to be elucidated. As antibodies against both $\mathrm{V} \beta 8.1$ and 8.2 were used in this study, at present it is not possible to differentiate the reactivities between these two subsets.

Induction of thymocyte apoptosis by administration of LPS in vivo has previously been demonstrated in
$\mathrm{BALB} / \mathrm{c}$ [27] and $\mathrm{C} 3 \mathrm{H} / \mathrm{HeN}$ mice, but not in $\mathrm{C} 3 \mathrm{H} / \mathrm{HeJ}$ mice [28]. The LPS-non-responder $\mathrm{C} 3 \mathrm{H} /$ HeJ mice were used in this study and it was confirmed that LPS did not cause an apoptotic effect on thymocytes of these mice. The presence of LPS in Y. enterocolitica SN preparation was, therefore, unlikely to account for the induction of apoptosis in thymocytes. 


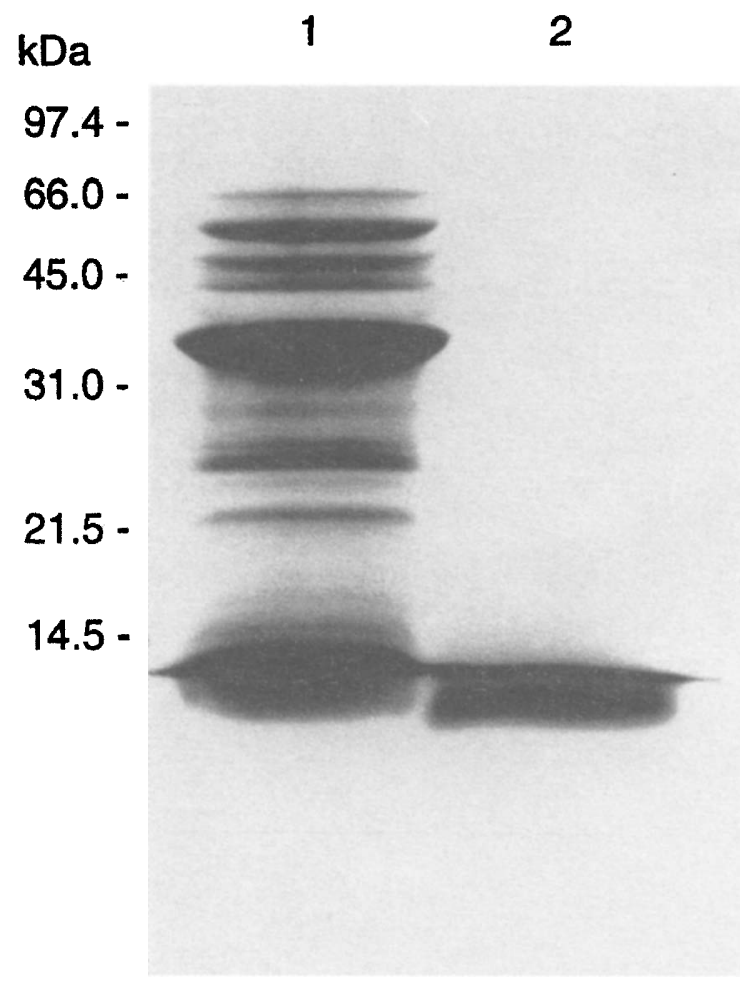

Fig. 8. SDS-PAGE analysis of the $Y$. enterocolitica products. $Y$. enterocolitica concentrated SN (lane 1, $40 \mu \mathrm{g}$ of protein in $20 \mu \mathrm{l}$ ) and CYG medium control (lane 2, 20 $\mu$ l) were subjected to SDS-PAGE, and the gel was stained with Coomassie Blue.

A number of recent reports showed that bacteria induced apoptosis in infected macrophages or neutrophils [19-23]. The present study showed the apoptotic effect of bacteria on thymocytes. The induction of thymocyte apoptosis may result from a direct effect of bacterial products on thymocytes or through the induction of cytokines and steroid hormones. Further studies in vitro should help to delineate whether or not a direct effect occurred. Tumour necrosis factor- $\alpha$ and interleukin 2-driven thymocyte death have previously been reported to be involved [28-30]. Production of cytokines had been demonstrated after $Y$. enterocolitica infection, although there was differential expression of some cytokines in susceptible and resistant strains of mice [31-33]. Further studies are needed to explore the involvement of cytokine and steroid hormones in thymocyte apoptosis induced by $Y$. enterocolitica. The protein patterns in $Y$. enterocolitica $\mathrm{SN}$ revealed the presence of many proteins bands with mol. wts between 65 and $17 \mathrm{kDa}$. The component(s) of $Y$. enterocolitica products in the $\mathrm{SN}$ which is(are) responsible for the induction of thymus atrophy await further characterisation. Whether the superantigen(s) produced by $Y$. enterocolitica may be involved remains to be seen.

We are grateful to Dr Hsiun-Ing Chen for assistance in the statistical analysis. This work was supported by grants NSC83-0412-B006-058 and NSC84-2331-B006-008 from the National Science Council, Republic of China.

\section{References}

1. Cornelis G, Laroche Y, Balligand G, Sory M-P, Wauters G. Yersinia enterocolitica, a primary model for bacterial invasiveness. Rev Infect Dis 1987; 9: 64-87.

2. Cover TL, Aber RC. Yersinia enterocolitica. $N$ Engl $J$ Med 1989; 321: 16-24.

3. Valtonen VV, Leirisalo M, Pentikäinen PJ et al. Triggering infections in reactive arthritis. Ann Rheum Dis 1985; 44: 399-405.

4. Lahesmaa-Rantala $\mathrm{R}$, Granfors $\mathrm{K}$, Isomäki $\mathrm{H}$, Toivanen A. Yersinia specific immune complexes in the synovial fluid of patients with Yersinia triggered reactive arthritis. Ann Rheum Dis 1987; 46: 510-514.

5. Granfors K, Jalkanen S, von Essen $\mathrm{R}$ et al. Yersinia antigens in synovial-fluid cells from patients with reactive arthritis. $N$ Engl $J$ Med 1989; 320: 216-221.

6. Lahesmaa R, Yssel H, Batsford S et al. Yersinia enterocolitica activates a $\mathrm{T}$ helper type 1-like $\mathrm{T}$ cell subset in reactive arthritis. J Immunol 1992; 148: 3079-3085.

7. Schlaak J, Hermann E, Ringhoffer $M$ et al. Predominance of Th1-type $\mathbf{T}$ cells in synovial fluid of patients with Yersiniainduced reactive arthritis. Eur $J$ Immunol 1992; 22: $2771-2776$.

8. Hermann E. T cells in reactive arthritis. APMIS 1993; 101: 177-186.

9. Skurnik M, Batsford S, Mertz A, Schiltz E, Toivanen P. The putative arthritogenic cationic 19-kilodalton antigen of Yersinia enterocolitica is a urease $\beta$-subunit. Infect Immun 1993; 61: 2498-2504.

10. Probst $\mathrm{P}$, Hermann E, Meyer zum Büschenfelde K-H, Fleischer B. Identification of the Yersinia enterocolitica urease $\beta$ subunit as a target antigen for human synovial $\mathrm{T}$ lymphocytes in reactive arthritis. Infect Immun 1993; 61: 4507-4509.

11. Marrack P, Kappler J. The staphylococcal enterotoxins and their relatives. Science 1990; 248: 705-711.

12. Fleischer B. Superantigens. Curr Opin Immunol 1992; 4: 392-395.

13. Schlievert PM. Role of superantigens in human disease. $J$ Infect Dis 1993; 167: 997-1002.

14. Abe J, Takeda T, Watanabe $\mathrm{Y}$ et al. Evidence for superantigen production by Yersinia pseudotuberculosis. J Immunol 1993; 151: $4183-4188$.

15. Ito $\mathrm{Y}$, Abe J, Yoshino $\mathrm{K}$, Takeda $\mathrm{T}$, Kohsaka $\mathrm{T}$. Sequence analysis of the gene for a novel superantigen produced by Yersinia pseudotuberculosis and expression of the recombinant protein. J Immunol 1995; 154: 5896-5906.

16. Miyoshi-Akiyama, T, Abe A, Kato H, Kawahara K, Narimatsu $\mathrm{H}$, Uchiyama T. DNA sequencing of the gene encoding a bacterial superantigen, Yersinia pseudotuberculosis-derived mitogen (YPM), and characterization of the gene product, cloned YPM. J Immunol 1995; 154: 5228-5234.

17. Stuart PM, Woodward JG. Yersinia enterocolitica produces superantigenic activity. J Immunol 1992; 148: 225-233.

18. Stuart PM, Munn RK, DeMoll E, Woodward JG. Characterization of human T-cell responses to Yersinia enterocolitica superantigen. Hum Immunol 1995; 43: 269-275.

19. Zychlinsky A, Prevost MC, Sansonetti PJ. Shigella flexneri induces apoptosis in infected macrophages. Nature 1992; 358: $167-169$.

20. Chen Y, Smith MR, Thirumalai K, Zynchlinsky A. A bacterial invasin induces macrophage apoptosis by binding directly to ICE. EMBO $J$ 1996; 15: 3853-3860.

21. Monack DM, Raupach B, Hromockyi AE, Falkow S Salmonella typhimurium invasion induces apoptosis in infected macrophages. Proc Natl Acad Sci USA 1996; 93: 9833-9838.

22. Watson RWG, Redmond HP, Wang JH, Condron C, BouchierHayes D. Neutrophils undergo apoptosis following ingestion of Escherichia coli. J Immunol 1996; 156: 3986-3992.

23. Baran J, Guzik K, Hryniewicz W, Ernst M, Flad H-D, Pryjma J. Apoptosis of monocytes and prolonged survival of granulocytes as a result of phagocytosis of bacteria. Infect Immun 1996; 64: 4242-4248.

24. Kawabe Y, Ochi A. Programmed cell death and extrathymic reduction of $\mathrm{VB} 8^{+} \mathrm{CD}^{+} \mathrm{T}$ cells in mice tolerant to Staphylococcus aureus enterotoxin B. Nature 1991; 349: 245-248.

25. Lin Y-S, Lei H-Y, Low TLK, Shen C-L, Chou L-J, Jan M-S. In vivo induction of apoptosis in immature thymocytes by 
staphylococcal enterotoxin B. J Immunol 1992; 149: $1156-$ 1163.

26. Kishimoto H, Surh CD, Sprent J. Upregulation of surface markers on dying thymocytes. $J$ Exp Med 1995; 181: 649-655.

27. Zhang Y-H, Takahashi K, Jiang G-Z, Kawai M, Fukada M Yokochi T. In vivo induction of apoptosis (programmed cell death) in mouse thymus by administration of lipopolysaccharide. Infect Immun 1993; 61: 5044-5048.

28. Wang S-D, Huang K-J, Lin Y-S, Lei H-Y. Sepsis-induced apoptosis of the thymocytes in mice. $J$ Immunol 1994; 152: 5014-5021.

29. Hernández-Caselles T, Stutman O. Immune functions of tumor necrosis factor. I. Tumor necrosis factor induces apoptosis of mouse thymocytes and can also stimulate or inhibit IL-6-induced proliferation depending on the concentration of mitogenic costimulation. J Immunol 1993; 151:
3999-4012.

30. Migliorati G, Nicoletti I, Pagliacci MC, D'Adamio L, Riccardi C. Interleukin-2 induces apoptosis in mouse thymocytes. Cell Immunol 1993; 146: 52-61.

31. Autenrieth IB, Beer M, Bohn E, Kaufmann SHE, Heesemann J. Immune responses to Yersinia enterocolitica in susceptible $\mathrm{BALB} / \mathrm{c}$ and resistant $\mathrm{C} 57 \mathrm{BL} / 6$ mice: an essential role for gamma interferon. Infect Immun 1994; 62: 2590-2599.

32. Autenrieth IB, Heesemann J. In vivo neutralization of tumo necrosis factor-alpha and interferon-gamma abrogates resistance to Yersinia enterocolitica infection in mice. Med Microbiol Immunol 1992; 181: 333-338.

33. Bohn E, Heesemann J, Ehlers S, Autenrieth IB. Early gamma interferon mRNA expression is associated with resistance of mice against Yersinia enterocolitica. Infect Immun 1994; 62 : $3027-3032$ 